\title{
EFFECT OF SEED HALOPRIMING ON IMPROVING SALT TOLERANCE IN Raphanus sativus L.
}

\author{
Milica M. Kanjevac, Biljana M. Bojović*, Marija S. Todorović, Milan S. Stanković
}

\author{
University of Kragujevac, Faculty of Science, Department of Biology and Ecology, \\ Radoja Domanovića 12, 34000 Kragujevac, Republic of Serbia \\ *Corresponding author; E-mail: biljana.bojovic@ pmf.kg.ac.rs
}

(Received March 2, 2021; Accepted April 10, 2021)

\begin{abstract}
In this paper, effect of halopriming on germination, initial growth and development of radish under salt stress conditions was investigated. The seeds were treated with different concentrations salts of calcium, potassium, and sodium chloride $\left(\mathrm{CaCl}_{2}, \mathrm{KCl}\right.$, $\mathrm{NaCl}$, respectively) in the form of a standard germination method and priming method, which involves modification of the metabolic activity of seeds in the pregerminative phase. The obtained results showed that all applied salts had inhibitory effects on germination characteristics (GP, RG and U, except MTG) and development of radish seedlings (shoot and root elongation, weight and vigour). Halopriming contributed to the improvement of tolerance to stress conditions, because the obtained values of all germination and growth characteristics were significantly increased. The best effect being achieved by priming with $\mathrm{CaCl}_{2}$ for germination characteristics and vigour and with $\mathrm{KCl}$ for initial development.
\end{abstract}

Keywords: radish, salt, halopriming, germination, growth, vigour.

\section{INTRODUCTION}

Radish (Raphanus sativus L.) is one of the more important varieties and it is a worldwide cultivated and consumed as a vegetable (WANG et al., 2013). It is known for a fleshy root, which is an important edible part. It contains a large amount of nutrients such as crude fibre, protein, carbohydrates, vitamin C (LU et al., 2008). It also has useful secondary metabolites, such as glucosinolates, polyphenols and isothiocyanates. The pharmaceutical potential of this species can be attributed to them (MANIVANNAN et al., 2019). Glucosinolates have a significant impact on the nutritional value and taste of radish and determine its final yield and quality (LU et al., 2008; WANG et al., 2013). Radish is categorized as a species that is sensitive to salt, and salinity is known to inhibit its growth. It has been previously confirmed that salt stress affected metabolic processes in seedlings, while in adults it caused chlorosis, various morphological and anatomical changes, as well as symptoms of nutrient deficiency (NOREEN and ASHRAF, 2009). Results of numerous studies showed that salt stress was negatively affect on plant height, chlorophyll content, and fresh weight of shoot and root of radish. There was wide variation in 
germination and growth parameters among the varieties of radish due to different level of salt applications (GHOSH et al., 2014; VISHNU PRIYA et al., 2020).

Salt stress affects the physiological and biochemical processes of plants, leading to a decrease in biomass production (AHMAD and SHARMA, 2012; AHMAD et al., 2012). The negative effect of salt stress is expressed on the whole plant and affects all developmental phases. Tolerance to salt stress varies from species to species and depends on the developmental plant stage, too (NAWAZ et al., 2010; AHMAD and SHARMA, 2012; AhMAD et al., 2012). Seedlings and young plants are significantly more sensitive to salt stress than mature plants. Mature plants are more resistant to salt because they regulate salt content and its circulation through tissues and organs in different ways (STEVANOVIĆ and JANKOVIĆ, 2001).

Soil salinity is the main limiting factor for crop yield and quality in agriculture. Soluble salts such as $\mathrm{CaCl}_{2}, \mathrm{KCl}$ and $\mathrm{NaCl}$ severely impair plant growth. The entry of these ions into the cells can lead to significant physiological disorders. High concentrations of $\mathrm{Na}^{+}$ions inhibit the absorption of potassium, which is an essential element for growth and development, resulting in lower productivity and may even lead to death (GUPTA and HUANG, 2014). Increased salinity causes oxidative ionic and osmotic stress. To balance cellular hyperosmolarity and ionic imbalance, plants have ability to accumulate osmolytes and osmoprotectants (CHANDNA et al., 2013). However, plant growth and development require a certain amount of $\mathrm{Ca}^{2+}, \mathrm{K}^{+}$and $\mathrm{Na}^{+}$ions in low concentrations (HARPER et al., 2004; TENORIOBERRÍO et al., 2018; QUEIROZ et al., 2020).

For maintenance of high productivity of consumed plants, various methods are used to reduce inhibitory effects of salinity and priming method stood out as one of the most effective. Seed priming treatments are simply applied method that can decrease the effects of salt stress and to improve the rate and speed of germination under stressed conditions (FULLER et al., 2012). Seed priming is a pregerminative treatment which achieves germination dynamics and plant performance by modulating metabolic activity in seed before radicle growth (TOUNEKTI et al., 2020). There are various priming methods that support plant growth and productivity, such as: hydro-, halo-, hormo-, osmo-, chemo- and biotic priming (PAPARELla et al., 2015). Primed seeds are characterized by a faster and more uniform appearance of seedlings, which can be useful in adverse soil conditions (KUBALA et al., 2015a,b).

In this paper, the influence of sodium, potassium and calcium salts on germination characteristics and initial growth and development of radish was investigated, as well as of increasing tolerance to stress, caused by the application of these salts, using of halopriming method. The aim of this study was to determine the degree of influence this method on germination, growth, biomass and vigour of radish seedlings.

\section{MATERIALS AND METHODS}

\section{Experimental design}

Seeds of Raphanus sativus L were obtained from commercial sources ("MORPHO d.o.o." Belgrade) and stored under optimal conditions (10-15 ${ }^{\circ} \mathrm{C}$ and $14-15 \%$ humidity). For the purposes of experiments, the seeds were surface sterilized with $0.1 \% \mathrm{NaClO}$ (sodium hypochlorite) solution and then washed with distilled water to $\mathrm{pH} \mathrm{7,} \mathrm{in} \mathrm{order} \mathrm{to} \mathrm{remove} \mathrm{the}$ epiphytic microflora. The experiment was done in three parts: one part (with the standard method of seed germination) was regarded as control; second part was done in salt stress conditions, using salts of sodium, potassium and calcium, without priming, and third part was conducted in salt stress conditions by halopriming method. In the second part of experiment, thirty seeds of radish were placed in 9-cm Petri dishes, lined with filter paper and treated with 
$10 \mathrm{ml}$ of $\mathrm{CaCl}_{2}, \mathrm{KCl}$ and $\mathrm{NaCl}$, in concentration of $25 \mathrm{mM}, 50 \mathrm{mM}$ and $75 \mathrm{mM}$ for each of these salts.

In the third part of experiment, seeds were primed with $25 \mathrm{mM} \mathrm{NaCl}, \mathrm{KCl}$ and $\mathrm{CaCl}_{2}$ for 24 h.This concentration, based on our previous research, had a stimulatory effect on the germination and growth of cultivated plants and as such is suitable to allow the seeds to adapt to subsequent salt stress caused by higher salt concentrations. After the priming, seeds were washed with distilled water and dried at room temperature $\left(22 \pm 2^{\circ} \mathrm{C}\right)$ for $48 \mathrm{~h}$.

After that, halo-primed seeds were subjected to 25,50 and $75 \mathrm{mM} \mathrm{CaCl}_{2}, \mathrm{KCl}$ and $\mathrm{NaCl}$ salinity. Prepared seeds from second and third parts of experiment, as well as control seeds were incubated in air chamber (photoperiod $16 / 8 \mathrm{~h}$, temperature $22 \pm 1^{\circ} \mathrm{C}$ ) for 15 days. The number of germinated seeds was determined every day, and the measurement of shoots and roots length, as well as fresh mass was performed on the fifteenth day.

\section{Seed germination}

The characteristics of germination were examined by measuring the total germination percentage (GP), mean time of germination (MTG), rate of germination (RG), as well as germination uniformity (U). Values were calculated according to FERNANDEZ et al. (2015) and ESPANANY et al. (2016) based on the following equations:

\section{Germination percentage}

$\mathrm{GP}=\frac{\text { Total seeds germination }}{\text { Total number of planted seeds }} \times 100$

Mean time of germination

$\mathrm{MTG}=\frac{\sum \mathrm{n}_{\mathrm{i}} \times \mathrm{t}_{\mathrm{i}}}{\sum \mathrm{n}_{\mathrm{i}}}$

$\mathrm{n}_{\mathrm{i}}=$ number of newly germinated seeds in the time $i$

$t_{i}=$ time from the start of experiment to the observation (in days)

Rate of germination

$\mathrm{RG}=\sum \frac{\mathrm{G}}{\mathrm{t}}$

$\mathrm{G}=$ seed germination at 1-day intervals (the percentage)

$\mathrm{t}=$ total germination period (in days).

\section{Germination uniformity}

$U=\frac{\mathrm{GP}}{\mathrm{MTG}}$

\section{Seedling growth}

Measurements of growth parameters were carry out in three series, where the length of the root and shoot was measured using a digital caliper, while measurements of fresh and dry mass were performed using an analytical weight. Shoot and root were separated to measure both of weight. For measure of dry weight, shoot and root were heated in thermostat oven at $105^{\circ} \mathrm{C}$ for $30 \mathrm{~min}$. Plant dry weight is equal to shoot dry weight plus root dry weight.

Seedling vigor index: It was calculated as per KHARAB et al. (1994) as under: 
Seedling Weight Vigor Index $(\mathrm{SWVI})=$ Mean seedling weight $\mathrm{x}$ GP

$\mathrm{GP}=$ Total germination $(\%)$

\section{Statistical analysis}

Each of the individual experiments was done in triplicate. The results obtained by using the SPSS software package for statistical data processing (SPSS for Windows, version 21), are expressed as the mean of three replicates \pm standard error (SE). The collected data were analyzed by the Mann-Whitney test with a significance threshold of $\mathrm{p} \leq 0.05$.

\section{RESULTS AND DISCUSSION}

\section{Seed germination}

Seed germination and initial growth of seedlings of many crops are most sensitive to the effects of salt stress (PATADE et al., 2011). Salinity can delay the start or reduce the germination rate leading to inhibited plant growth which ultimately results in reduced of plant productivity. It is known that halopriming can alleviate the effects of salt stress by strengthening the antioxidant system and increasing protein accumulation (ASHRAF and FOOLAD, 2005REHMAN et al., 2014; WOJTYLA et al., 2016).

The results obtained by examining the germination characteristics of radish in different concentrations of calcium, potassium, and sodium salts, without seed priming, are shown in the Tab 1.

Table 1. Effect of different concentrations of $\mathrm{CaCl}_{2}, \mathrm{KCl}$ and $\mathrm{NaCl}$ on germination characteristics of Raphanus sativus L. (without priming):

GP - germination percentage; MTG - mean time of germination; RG - rate of germination;

$\mathrm{U}-$ germination uniformity.

\begin{tabular}{llcccc}
\hline \multicolumn{1}{l}{ Treatment } & GP & MTG & RG & U \\
\hline \multirow{3}{*}{ CaCl2 } & $\mathbf{2 5} \mathbf{~ m M}$ & $45.56 \pm 4.44$ & $2.54 \pm 0.34$ & $34.08 \pm 4.97$ & $18.93 \pm 4.08$ \\
& $\mathbf{5 0 ~} \mathbf{~ M M}$ & $41.11 \pm 7.78$ & $2.82 \pm 0.06$ & $28.52 \pm 5.07$ & $14.49 \pm 2.50$ \\
& $\mathbf{7 5} \mathbf{~ m M}$ & $31.11 \pm 4.01^{*}$ & $3.30 \pm 0.24$ & $19.81 \pm 3.22^{*}$ & $9.69 \pm 1.87^{*}$ \\
\hline \multirow{3}{*}{ KCl } & $\mathbf{2 5} \mathbf{~ m M}$ & $52.22 \pm 7.29$ & $3.07 \pm 0.04^{*}$ & $34.26 \pm 4.91$ & $17.06 \pm 2.46$ \\
& $\mathbf{5 0} \mathbf{~ m M}$ & $52.22 \pm 7.78$ & $2.89 \pm 0.27$ & $36.30 \pm 7.06$ & $18.70 \pm 3.89$ \\
& $\mathbf{7 5} \mathbf{~ m M}$ & $53.33 \pm 5.77$ & $2.84 \pm 0.55$ & $37.59 \pm 7.41$ & $20.62 \pm 4.85$ \\
\hline \multirow{3}{*}{ NaCl } & $\mathbf{2 5} \mathbf{~ m M}$ & $52.22 \pm 6.76$ & $3.04 \pm 0.15$ & $35.18 \pm 3.72$ & $17.11 \pm 1.71$ \\
& $\mathbf{5 0 ~} \mathbf{~ m M}$ & $27.78 \pm 1.11^{*}$ & $2.77 \pm 0.35$ & $19.44 \pm 0.96^{*}$ & $10.24 \pm 0.90^{*}$ \\
& $\mathbf{7 5} \mathbf{~ m M}$ & $40.00 \pm 3.85$ & $2.08 \pm 0.27$ & $32.78 \pm 4.34$ & $20.50 \pm 4.85$ \\
\hline Control & & $51.11 \pm 5.56$ & $2.47 \pm 0.19$ & $40.37 \pm 4.91$ & $20.88 \pm 2.76$ \\
\hline
\end{tabular}

The results are presented as the mean of three measurements \pm standard error. An asterisk (*) indicates a statistically significant difference $(\mathrm{p} \leq 0.05)$ in relation to the values in the control.

It was found that all salt solutions and all concentrations had an inhibitory effect on the rate of germination (R), uniformity of germination (U), as well as germination percentage (except $\mathrm{KCl}$ ), while stimulatory effect was recorded for mean time of germination (MTG). Acording to the obtained values, the applied treatments caused a significant decrease in values for $\mathrm{R}$ and $\mathrm{U}$. However, certain salts exhibited a slight stimulatory effect on germination percentage (GP) compared to the control. Thus, all applied concentrations of $\mathrm{KCl}$ and $25 \mathrm{mM}$ 
$\mathrm{NaCl}$ had a slight stimulatory effect on the percentage of germination, whereas $75 \mathrm{mM} \mathrm{KCl}$ $(53.33 \%)$ had only a moderate stimulatory effect on GP. The lowest percentage of germination was achieved in treatment with $50 \mathrm{mM} \mathrm{NaCl}(27.78 \%)$, where a statistically significant difference was recorded.

The applied halopriming method had a stimulating effect on the germination characteristics of radish under salt-stress conditions, and statistically significant differences were found among all monitored values (Tab. 2). The most prominent effect on the germination percentage was achieved in treatment with $75 \mathrm{mM} \mathrm{CaCl}_{2}$ (85.56\%) and $25 \mathrm{mM} \mathrm{NaCl}$ (78.89\%). Halopriming treatments cause faster germination, and the most significant effect on MTG was achieved in $75 \mathrm{mM} \mathrm{KCl} \mathrm{(1.36)} \mathrm{and} 25 \mathrm{mM} \mathrm{NaCl}$ (1.37). At the same time, the treatments with the highest percentage of germination were accompanied by the highest values for germination rate and uniformity. It is evident that halopriming contributed to the development of salt tolerance during seed germination.

Table 2. Effect of halopriming on germination characteristics of Raphanus sativus L.: GP - germination percentage; MTG - mean time of germination; RG - rate of germination; $\mathrm{U}-$ germination uniformity.

\begin{tabular}{|c|c|c|c|c|c|}
\hline \multicolumn{2}{|c|}{ Treatment } & GP & MTG & RG & $\mathbf{U}$ \\
\hline \multirow{3}{*}{$\mathrm{CaCl}_{2}$} & $25 \mathrm{mM}$ & $71.11 \pm 5.56^{*}$ & $1.40 \pm 0.23 *$ & $65.78 \pm 4.62 *$ & $52.60 \pm 7.11 *$ \\
\hline & $50 \mathrm{mM}$ & $74.44 \pm 2.94 *$ & $1.48 \pm 0.06^{*}$ & $67.34 \pm 2.67 *$ & $50.54 \pm 2.50 *$ \\
\hline & $75 \mathrm{mM}$ & $85.56 \pm 4.84 *$ & $1.41 \pm 0.007 *$ & $78.44 \pm 3.47^{*}$ & $60.85 \pm 1.78^{*}$ \\
\hline \multirow{3}{*}{ KCl } & $25 \mathrm{mM}$ & $75.56 \pm 2.94 *$ & $1.63 \pm 0.13^{*}$ & $66.22 \pm 4.42 *$ & $47.25 \pm 5.67 *$ \\
\hline & $50 \mathrm{mM}$ & $72.22 \pm 9.69$ & $1.63 \pm 0.27^{*}$ & $63.33 \pm 9.71$ & $47.28 \pm 10.18^{*}$ \\
\hline & $75 \mathrm{mM}$ & $72.22 \pm 5.55^{*}$ & $1.36 \pm 0.07 *$ & $66.89 \pm 4.24 *$ & $53.01 \pm 2.00^{*}$ \\
\hline \multirow{3}{*}{$\mathrm{NaCl}$} & $25 \mathrm{mM}$ & $78.89 \pm 4.84^{*}$ & $1.37 \pm 0.09 *$ & $72.89 \pm 3.28 *$ & $57.76 \pm 1.54 *$ \\
\hline & $50 \mathrm{mM}$ & $73.33 \pm 1.93 *$ & $1.52 \pm 0.05^{*}$ & $65.78 \pm 2.35^{*}$ & $48.53 \pm 2.68 *$ \\
\hline & $75 \mathrm{mM}$ & $70.00 \pm 3.85^{*}$ & $1.44 \pm 0.20 *$ & $64.00 \pm 5.34 *$ & $50.92 \pm 8.74 *$ \\
\hline \multicolumn{2}{|c|}{ Control } & $51.11 \pm 5.56$ & $2.47 \pm 0.19$ & $40.37 \pm 4.91$ & $20.88 \pm 2.76$ \\
\hline
\end{tabular}

The results are presented as the mean of three measurements \pm standard error. An asterisk (*) indicates a statistically significant difference $(\mathrm{p} \leq 0.05)$ in relation to the values in the control.

Unfavourable germination characteristics conditioned by different concentrations of salts, are caused by the physical damage and the toxic effect of some salts on the seed radical. Improved seed germination performance by halopriming could be due to osmotic adaptation of seeds to increased water intake or accelerated cell division (BITTENCOURT et al., 2005). The results were similar with those from previous studies, which confirmed the positive impact of halopriming on germination performance of tomato and mustard (ZHANG et al., 2012; AHMED et al., 2017; BISWAS et a1., 2019). It is especially important that salt solutions applied in halopriming form, have the property of growth regulators. $\mathrm{A} \mathrm{Ca}{ }^{2+}$ ions from $\mathrm{CaCl}_{2}$ plays a key role in maintaining and preserving the structural integrity of the cell, which is especially important for seed germination. In addition, during germination, it modulates the activity of phosphatase and kinase enzymes involved in the translation process (HARPER et al., 2004). Potassium ion $\left(\mathrm{K}^{+}\right)$is an essential nutrient of plants that plays an important role in the biochemical and physiological processes of plants (TENORIO-BERRÍO et al., 2018). $\mathrm{A} \mathrm{K}^{+}$ deficiency leads to growth inhibition due to its crucial role in maintaining cell turgor, membrane potential and enzyme activity (JOUYBAN, 2012). Optimal $\mathrm{K}^{+}$concentration (approximately 100 $\mathrm{mM}$ ) is required for enzyme activation and protein synthesis in plants (DREYER and UOzUMI, 2011). Higher intake of mineral elements, such as $\mathrm{K}^{+}$, is an important mechanism of salt tolerance for most crops (GURMANI et al., 2006). However, $\mathrm{K}^{+}$ion at concentrations higher than $100 \mathrm{mM}$ can cause salt stress and adversely affect growth, morphology, oxidative stress levels 
and antioxidant enzyme activity of plants (HASSINI et al., 2017). Similarly, a certain amount of sodium ions $\left(\mathrm{Na}^{+}\right)$is necessary for plant growth and a low concentration of these ions is beneficial, as opposed to a high concentration that is harmful to plants (QUEIROZ et al., 2020).

\section{Seedling growth}

Dynamic changes in the initial stages of growth and development of $R$. sativus, under the influence different concentration salt of calcium, potassium, and sodium, without seed priming, are presented in Tab. 3. Salt solutions exhibited inhibitory effects on shoot and root elongation and statistical significance was recorded at the highest concentration of applied salts $(75 \mathrm{mM})$. It has been previously confirmed that increase of $\mathrm{NaCl}$ salinity and $\mathrm{Na}^{+}$ion accumulation in photosynthetic tissues results in reduced seedling growth (OKÇU et al., 2005; DAVENPORT et al., 2005). However, in treatments with lower concentrations of $\mathrm{NaCl}$ and $\mathrm{KCl}$, obtained values were higher when compared with control. Almost all applied treatments had a positive effect on fresh and dry weight. Contrary, KAYA and DAY (2008) suggested that ionic and osmotic stress could lead to a reduction in seedling biomass.

Table 3. Effect of different concentrations of $\mathrm{CaCl}_{2}, \mathrm{KCl}$ and $\mathrm{NaCl}$ on shoot and root length (cm) and weight (g) of Raphanus sativus L. (without priming).

\begin{tabular}{llcccc}
\hline \multicolumn{2}{l}{ Treatment } & Shoot length & Root length & Fresh weight & Dry weight \\
\hline \multirow{3}{*}{ CaCl 2} & $\mathbf{2 5} \mathbf{~ m M}$ & $3,51 \pm 0,25$ & $4,93 \pm 0,79$ & $0,087 \pm 0,01$ & $0,0095 \pm 0,00^{*}$ \\
& $\mathbf{5 0} \mathbf{~ m M}$ & $2,72 \pm 0,31^{*}$ & $5,28 \pm 0,57$ & $0,086 \pm 0,02$ & $0,0107 \pm 0,00^{*}$ \\
& $\mathbf{7 5} \mathbf{~ m M}$ & $2,73 \pm 0,15^{*}$ & $1,25 \pm 0,07^{*}$ & $0,088 \pm 0,00$ & $0,0117 \pm 0,00^{*}$ \\
\hline \multirow{3}{*}{$\mathbf{K C l}$} & $\mathbf{2 5} \mathbf{~ m M}$ & $3,60 \pm 0,26$ & $5,47 \pm 0,32$ & $0,095 \pm 0,01$ & $0,0095 \pm 0,00$ \\
& $\mathbf{5 0} \mathbf{~ m M}$ & $4,50 \pm 0,51$ & $5,98 \pm 0,64$ & $0,106 \pm 0,02$ & $0,0108 \pm 0,00^{*}$ \\
& $\mathbf{7 5} \mathbf{~ m M}$ & $1,87 \pm 0,19^{*}$ & $2,20 \pm 0,23^{*}$ & $0,068 \pm 0,00$ & $0,0083 \pm 0,00$ \\
\hline \multirow{2}{*}{$\mathbf{N a C l}$} & $\mathbf{2 5} \mathbf{~ m M}$ & $5,90 \pm 0,65^{*}$ & $14,17 \pm 0,67^{*}$ & $0,145 \pm 0,01^{*}$ & $0,0097 \pm 0,00$ \\
& $\mathbf{5 0} \mathbf{~} \mathbf{M}$ & $3,65 \pm 0,24$ & $10,34 \pm 0,50^{*}$ & $0,113 \pm 0,02$ & $0,0089 \pm 0,00$ \\
& $\mathbf{7 5} \mathbf{~} \mathbf{M}$ & $2,88 \pm 0,23^{*}$ & $5,48 \pm 0,40$ & $0,085 \pm 0,01$ & $0,0077 \pm 0,00$ \\
\hline Control & & $3,86 \pm 0,18$ & $7,09 \pm 0,69$ & $0,081 \pm 0,01$ & $0,0074 \pm 0,00$ \\
\hline
\end{tabular}

The results are presented as the mean of three measurements \pm standard error. An asterisk (*) indicates a statistically significant difference $(\mathrm{p} \leq 0.05)$ in relation to the values in the control.

Table 4. Effect of halopriming on shoot and root length $(\mathrm{cm})$ and weight ( $\mathrm{g}$ ) of Raphanus sativus L. seedlings.

\begin{tabular}{cccccc}
\hline \multicolumn{2}{c}{ Treatment } & Shoot length & Root length & Fresh weight & Dry weight \\
\hline \multirow{3}{*}{$\mathbf{C a C l}_{2}$} & $\mathbf{2 5} \mathbf{~ m M}$ & $3,82 \pm 0,15$ & $13,75 \pm 0,50^{*}$ & $0,100 \pm 0,00^{*}$ & $0,0082 \pm 0,00$ \\
& $\mathbf{5 0} \mathbf{~ m M}$ & $3,62 \pm 0,14$ & $13,14 \pm 0,61^{*}$ & $0,103 \pm 0,01$ & $0,0078 \pm 0,00$ \\
& $\mathbf{7 5} \mathbf{~ m M}$ & $3,68 \pm 0,17$ & $13,10 \pm 0,55^{*}$ & $0,109 \pm 0,01^{*}$ & $0,0089 \pm 0,00$ \\
\hline \multirow{3}{*}{ KCl } & $\mathbf{2 5} \mathbf{~ m M}$ & $3,76 \pm 0,15$ & $13,80 \pm 1,01^{*}$ & $0,090 \pm 0,00$ & $0,0080 \pm 0,00$ \\
& $\mathbf{5 0 ~} \mathbf{~ M M}$ & $4,06 \pm 0,25$ & $13,92 \pm 0,36^{*}$ & $0,109 \pm 0,01^{*}$ & $0,0068 \pm 0,00$ \\
& $\mathbf{7 5} \mathbf{~ m M}$ & $4,10 \pm 0,33$ & $9,30 \pm 1,18$ & $0,113 \pm 0,00^{*}$ & $0,0080 \pm 0,00$ \\
\hline \multirow{3}{*}{$\mathbf{N a C l}$} & $\mathbf{2 5} \mathbf{~ m M}$ & $3,22 \pm 0,30$ & $9,67 \pm 0,41^{*}$ & $0,085 \pm 0,00$ & $0,0074 \pm 0,00$ \\
& $\mathbf{5 0 ~} \mathbf{~ m M}$ & $3,94 \pm 0,21$ & $12,81 \pm 0,82^{*}$ & $0,093 \pm 0,00$ & $0,0073 \pm 0,00$ \\
& $\mathbf{7 5} \mathbf{~ m M}$ & $3,24 \pm 0,18^{*}$ & $9,72 \pm 0,48^{*}$ & $0,074 \pm 0,00$ & $0,0075 \pm 0,00$ \\
\hline \multicolumn{2}{c}{ Control } & $3,86 \pm 0,18$ & $7,09 \pm 0,69$ & $0,081 \pm 0,01$ & $0,0074 \pm 0,00$ \\
\hline
\end{tabular}

The results are presented as the mean of three measurements \pm standard error. An asterisk (*) indicates a statistically significant difference $(\mathrm{p} \leq 0.05)$ in relation to the values in the control. 
Halopriming treatments had a beneficial effect on elongation, fresh and dry mass of radish (Tab. 4). Applied treatments caused a significant increase, especially of root length, in compared to untreated seedlings, with the highest value recorded in the treatment with $\mathrm{KCl}$ and $\mathrm{CaCl}_{2}$. The best effect on shoot length was achieved by treatments with $\mathrm{KCl}$. The values obtained for fresh and dry mass were higher in compared to untreated seedlings in almost all applied treatments. This confirmed that halopriming using in pre-germinative phase improving salt tolerance in development of radish seedlings. Data obtained by monitoring plant growth indicate that the applied treatments in the form of priming achieved a significantly effect in compared to the standard method of germination, without priming. It has been confirmed that priming with inorganic salts have a stimulatory effect on germination, elongation, as well as on plant biomass (FAROOQ et al., 2011). In this study, it was shown that salts with the same osmotic potential had a different stimulatory effect on the elongation of radish seedlings, where treatments with $\mathrm{KCl}$ were the most superior. The increase of seedling length may be a consequence of increased nuclear replication in the shoot and root, which occurs under the influence of halopriming (SHEHZAD et al., 2012). The obtained results are consistent with previous studies, which showed that seed halopriming has a significant effect on shoot and root length (MAVi et al., 2006; PATADE et al., 2009; RATIKANTA et al., 2013; AHMED et al., 2017). Furthermore, improved seedling biomass values may be due to enhancement cell division of the apical root meristem, leading to increased plant growth (SHEHZAD et al., 2012). Just a few priming treatments showed a slight inhibitory effect on fresh and/or dry biomass of radish seedlings.

\section{Seedling vigor}

Seedling vigor is a important parameter which determines the potential for rapid and uniform emergence of plants under a wide range of field conditions, and mainly reflects seedling weight (SWVI) or height (SLVI), which usually neglects germination speed (VANDAMME et al., 2016). In case of standard method of germination, based on SLVI index, it was noted that treatment with $25 \mathrm{mM} \mathrm{NaCl}$ was most favourable for seed germination and early stage of radish development. In contrast, adverse effects on SLVI values were observed in other treatments (Tab. 5). In relation to the SLVI, the treatment with $25 \mathrm{mM}$ and $50 \mathrm{mM} \mathrm{KCl}$ had a positive effect on the SWVI index, as well as the treatment with $25 \mathrm{mM} \mathrm{NaCl}$ where the highest value was also recorded.

Table 5. Effect of different methods of germination on seedling length (SLVI) and seedling weight (SWVI) vigor index of Raphanus sativus $\mathrm{L}$.

\begin{tabular}{|c|c|c|c|c|c|}
\hline \multirow{2}{*}{\multicolumn{2}{|c|}{ Treatment }} & \multicolumn{2}{|c|}{ Standard method (without priming) } & \multicolumn{2}{|c|}{ Priming method } \\
\hline & & SLVI & SWVI & SLVI & SWVI \\
\hline \multirow{3}{*}{$\mathrm{CaCl}_{2}$} & $25 \mathrm{mM}$ & $384.50 \pm 37.50^{*}$ & $3.98 \pm 0.39$ & $1249.46 \pm 97.63^{*}$ & $7.12 \pm 0.56^{*}$ \\
\hline & $50 \mathrm{mM}$ & $328.88 \pm 62.21 *$ & $3.52 \pm 0.67$ & $1247.67 \pm 49.27 *$ & $7.68 \pm 0.31 *$ \\
\hline & $75 \mathrm{mM}$ & $123.82 \pm 15.95^{*}$ & $2.73 \pm 0.35^{*}$ & $1435.64 \pm 81.24 *$ & $9.34 \pm 0.53^{*}$ \\
\hline \multirow{3}{*}{$\mathrm{KCl}$} & $25 \mathrm{mM}$ & $473.67 \pm 66.10$ & $4.94 \pm 0.69$ & $1326.78 \pm 51.63 *$ & $6.80 \pm 0.26^{*}$ \\
\hline & $50 \mathrm{mM}$ & $547.30 \pm 81.52$ & $5.56 \pm 0.83$ & $1294.24 \pm 173.56^{*}$ & $7.89 \pm 1.06^{*}$ \\
\hline & $75 \mathrm{mM}$ & $217.05 \pm 23.50 *$ & $3.64 \pm 0.40$ & $967.79 \pm 74.41 *$ & $8.19 \pm 0.63^{*}$ \\
\hline \multirow{3}{*}{$\mathrm{NaCl}$} & $25 \mathrm{mM}$ & $1048.05 \pm 135.53^{*}$ & $7.56 \pm 0.98^{*}$ & $1016.89 \pm 62.44^{*}$ & $6.71 \pm 0.41^{*}$ \\
\hline & $50 \mathrm{mM}$ & $388.64 \pm 15.53^{*}$ & $3.14 \pm 0.12$ & $1228.33 \pm 32.25^{*}$ & $6.81 \pm 0.18^{*}$ \\
\hline & $75 \mathrm{mM}$ & $334.40 \pm 32.19 *$ & $3.38 \pm 0.32$ & $907.20 \pm 49.91 *$ & $5.21 \pm 0.29 *$ \\
\hline \multicolumn{2}{|c|}{ Control } & $558.69 \pm 61.84$ & $4.16 \pm 0.45$ & $558.69 \pm 61.84$ & $4.16 \pm 0.45$ \\
\hline
\end{tabular}

The results are presented as the mean of three measurements \pm standard error. An asterisk $(*)$ indicates a statistically significant difference $(\mathrm{p} \leq 0.05)$ in relation to the values in the control. 
By studying SLVI and SWVI index values using halopriming method, a stimulatory effect was observed for each of the applied treatments, where the obtained values were multiplied compared to the values measured in the control, where the greatest stimulatory effect shown by treatment with $75 \mathrm{mM} \mathrm{CaCl} 2$. It is important to emphasize that in all applied treatments, obtained values for the vigor index were statistically significant.

Observing the SLVI and SWVI index valuesfor both of methods and considering that seedlings with high vigor index will develop into more resistant plants with better growth, it can be assumed that radish seedlings treated with appropriate concentrations of salts in pregerminative stage, would have the ability to grows faster and copes with unfavourable environmental conditions (MONDO et al., 2013). The results are agreement with previous studies, which confirmed that the harmful effects of abiotic stress of plants can be reduced by pre-sowing halopriming (KHAN et al., 2009; MAITI et al., 2011; RAIKANTA et al., 2013).

Nowadays, seed industry uses seed vigor to evaluate seed quality. High seed vigor is associated with the potential for increasing growth and productivity in agricultural production.

\section{CONCLUSION}

The advantages of the priming method over the standard seed germination method in developing tolerance Raphanus sativus seedling to salt stress have been investigated. In the connection, the effect of different concentrations of sodium, potassium, and calcium salts on germination and initial growth was considered. The applied treatments have shown different potential in the initial stages of growth and development. It has been recorded that salts with the same osmotic potential had a different effect on the monitored characteristics and the treatments applied in the form of priming showed an overall superior effect. According to the results of this study, all halopriming treatments had significantly stimulative effect on germination, and growth of radish seedlings. Based on the mentioned facts, the application of the halopriming method can be recommended to improve the tolerance of cultivated plants under conditions of increased soil salinity.

\section{Acknowledgments}

This work was supported by the Serbian Ministry of Education, Science and Technological Development (Agreement No. 451-03-9/2021-14/200122).

\section{References:}

[1] Ahmad, P., Kumar, A., Ashraf, M., Akram, N.A. (2012): Salt-induced changes in photosynthetic activity and oxidative defense system of three cultivars of mustard (Brassica juncea L.). African Journal of Biotechnology 11 (11): 2694-2703. doi: 10.5897/AJB11.3203

[2] Ahmad, P., Sharma, S. (2012): Physio-biochemical attributes in two cultivars of mulberry (Morus alba L.) under NaHCO3 stress. International Journal of Plant Production 4 (2): 79-86. doi: 10.22069/IJPP.2012.685

[3] Ahmed, Z., Anwar, S., Baloch, A.R., Ahmed S, Muhammad F, Alizai N.A, Ahmed M., KHAN S, FAISAL S. (2017): Effect of halopriming on seed germination and seedling vigor of solanaceous vegetables. Journal of Natural Sciences Research 7 (9): 9 pages. 
[4] Ashraf, M., FoOlaD, M.R. (2005): Pre-sowing seed treatment - a shotgun approach to improve germination, plant growth, and crop yield under saline and non-saline conditions. Advances Agronomy 88: 223-271. doi: 10.1016/S00652113(05)88006-X

[5] Biswas, S., Rasal-Monir, M.D., Islam, M., ModaK, S., Humayun KabiR, M. (2019): Induction of Salt Tolerance in Tomato Through Seed Priming. Plant 7 (3): 47-53. doi: 10.11648/j.plant.20190703.14

[6] Bittencourt, M.L.C., Dias, D.C.F.S., Dias, L.A.S., Araujo, E. (2005): Germination and vigour of primed asparagus seeds. Scientia Agricola (Piracicaba, Braz.) 62 (4): 319324.

[7] Bojović, B., Jakovluević, D., ĆurČıć, S., Stanković, M. (2018): Phytotoxic potential of common nettle (Urtica dioica L.) on germination and early growth of cereals an vegetables. Allelopathy Journal 43 (2): 175-186.

[8] Chandna, R., Azooz, M.M., Ahmad, P. (2013): Recent advances of metabolomics to reveal plant response during salt stress. In: Ahmad, P., Azooz, M.M., Prasad, M.N.V. (eds) Salt Stress in Plants 1-14. Springer, New York, NY. doi.org/10.1007/978-1-46146108-1_1

[9] Davenport, R., James, R.A., Plogander, A.Z., Tester M., Munns, R. (2005): Control of sodium transport in durum wheat. Plant Physiology 137: 807-818. doi: 10.1104/pp.104.057307

[10] Dreyer, I., UOZUMI, N. (2011): Potassium channels in plant cells. The FEBS Journal 278 (22): 4293-4303. doi: 10.1111/j.1742-4658.2011.08371.x

[11] Espanany, A., Fallah, S., TAdayyon, A. (2016): Seed priming improves seed germination and reduces oxidative stress in black cumin (Nigella sativa) in presence of cadmium. Industrial Crops and Products 79: 195-204.

doi: 10.1016/j.indcrop.2015.11.016

[12] Farooq, M., Aziz, T., ur Rehman, H., Ur Rehman, A., Cheema, S.A., AzIz, T. (2011): Evaluating surface drying and re-drying for wheat seed priming with polyamines: effects on emergence, early seedling growth and starch metabolism. Acta Physiol Plant 33: 17071713. doi: 0.1007/s11738-010-0707-3

[13] Fernandez, I.C.D, LuQue, E.G., Mercado, F.G., Marrero, J.M. (2015): Germination responses of Limonium insigne (Coss.) Kuntze to salinity and temperature. Pakistan Journal of Botany 47: 807-812.

[14] Fuller, M., Hamza, J., Rihan, H., Al-Issawi, M. (2012): Germination of primed seed under $\mathrm{NaCl}$ stress in wheat. International Scholarly Research Network, ISRN Botany Article ID 167804, 5 pages. doi: 10.5402/2012/167804.

[15] Ghosh, P., Kumar Dash, P., Sarker, R., Mannan, A. (2014): Effect of salinity on germination, growth and yield of radish (Raphanus sativus L.) varieties. International Journal of Biosciences 5 (1): 37-48. doi: 10.12692/ijb/5.1.37-48

[16] Gupta, B., HuANG, B. (2014): Mechanism of salinity tolerance in plants: physiological, biochemical, and molecular characterization. International journal of genomics, Article ID 701596, 18 pages. doi: 10.1155/2014/701596

[17] Gurmani, A.R., BANO, A., SALim, M. (2006): Effect of growth regulators on growth, yield and ions accumulation of rice (Oryza sativa 1.) under salt stress. Pakistan Journal of Botany 38 (5): 1415-1424. 
[18] Harper, J.F., Breton, G., Harmon, A. (2004): Decoding $\mathrm{Ca}^{2+}$ signals through plant protein kinases. Annual Review of Plant Biology 55: 263-288.

doi: 10.1146/annurev.arplant.55.031903.141627

[19] Hassanpouraghdam, M.B, Pardaz, J.E., AkHTar, N.F. (2009): The effect of osmopriming on germination and seedling growth of Brassica napus L. under salinity conditions. Journal of Food, Agriculture \& Environment 7: 620-622.

[20] Hassini, I., Martinez-Ballesta, M.D., Boughanmi, N., Moreno, D.A., Carvajal, M. (2017): Improvement of broccoli sprouts (Brassica oleracea L. var. italica) growth and quality by $\mathrm{KCl}$ seed priming and methyl jasmonate under salinity stress. Scientia Horticulturae 226: 141-151. doi: 10.1016/j.scienta.2017.08.030

[21] Jasim, A., Mudhar, W., Timmen, A.A., SAad, A. (2016): Effect of salt stress on plant growth and free endogenous hormones of primed radish (Raphanus sativus L.) seeds with salicylic acid. International Journal of Chem. Tech. Research 9 (6): 339-346.

[22] JouYBan, Z. (2012): The effects of salt stress on plant growth. Technical Journal of Engineering and Applied Sciences 2 (1): 7-10.

[23] KAYA, M.D., DAY, S. (2008): Relationship between seed size and $\mathrm{NaCl}$ on germination, seed vigor and early seedling growth of sunflower (Helianthus annuus L.). African Journal of Agricultural Research 3 (11): 787-791.

[24] Khan, H.A., Ayub, C.M., Pervez, M.A., Bilal, R.M., Shahid, M.A., Ziaf, K. (2009): Effect of seed priming with $\mathrm{NaCl}$ on salinity tolerance of hot pepper (Capsicum annuиm L.) at seedling stage. Soil \& Environment 28 (1): 81-87.

[25] Kharab, R.P.S., LATher, B.P.S. and Deswal, D.P. (1994): Prediction of field emergence through heritability and genetic advance of vigour parameters. Seed Science and Technology 22: 461-466.

[26] Kubala, S., Garnczarska, M., Wojtyla, Ł., Clippe, A., Kosmala, A., ŻmieńKo, A., LUTTS, S., QUINET, M. (2015a): Deciphering priming-induced improvement of rapeseed (Brassica napus L.) germination through an integrated transcriptomic and proteomic approach. Plant Science 231: 94-113. doi: 10.1016/j.plantsci.2014.11.008

[27] Kubala, S., Wojtyla, Ł, Quinet, M., Lechowska, K., LutTs, S., Garnczarska, M. (2015b): Enhanced expression of the proline synthesis gene P5CSA in relations to seed osmopriming improvement of Brassica napus germination under salinity stress. Journal of Plant Physiology 183: 1-12. doi: 10.1016/j.jplph.2015.04.009

[28] LU, Z.L., LiU, L. W., LI, X.Y., Gong, Y.Q., Hou, X.L., ZhU, X.W., WANG, L.Z. (2008): Analysis and evaluation of nutritional quality in Chinese radish (Raphanus sativus L.). Agricultural Sciences in China 7 (7): 823-830.

[29] Maiti, R.K., Vidyasagar, P., Rajkumar, D., Ramaswamy, A., Rodriguez, H.G. (2011): Seed priming improves seedling vigor and yield of few vegetable crops. International Journal of Bio-resource and Stress Management 2 (1): 125-130.

[30] Manivannan, A., Kim, J. H., Kim, D.S., LeE, E.S., LeE, H.E. (2019): Deciphering the nutraceutical potential of Raphanus sativus - A comprehensive overview. Nutrients 11 (2): 402. doi: 10.3390/nu11020402

[31] MAVI, K., ERMIS, S., DEMIR, I. (2006): The effect of priming on tomato rootstock seeds in relation to seedling growth. Asian Plant Science 5: 940-947. doi: ajps.2006.940.947

[32] Mondo, V.H.V., Cicero, S.M., Dourado-Neto, D., Pupim, T.L., Dias, M.A.N. (2013): Seed vigor and initial growth of corn crop. Journal of Seed Science 35: 64-69. 
[33] Nawaz, K., Hussain, K., Majeed, A., Khan, F., Afghan, S., Ali, K. (2010): Fatality of salt stress to plants: Morphological, physiological and biochemical aspects. African Journal of Biotechnology 9 (34): 5475-5480.

[34] Noreen, Z., Ashraf, M. (2009): Changes in antioxidant enzymes and some key metabolites in some genetically diverse cultivars of radish (Raphanus sativus L.). Environmental and Experimental Botany 67 (2): 395-402. doi: 10.1016/j.envexpbot.2009.05.011

[35] ОкÇU, G., KaYA M.D., АTAK M. (2005): Effects of salt and drought stresses on germination and seedling growth of pea (Pisum sativum L.). Turkish Journal of Agriculture and Forestry 29 (4): 237-242.

[36] Paparella, S., Araújo, S.S., Rossi, G., Wijayasinghe, M., Carbonera, D., BALESTRAZZI, A. (2015): Seed priming: state of the art and new perspectives. Plant Cell Reports 34: 1281-1293.

[37] Patade, V.Y., Bhargava, S., Suprasanna, P. (2009): Halopriming imparts tolerance to salt and PEG induced drought stress in sugarcane. Agriculture, Ecosystems \& Environment 134 (1-2): 24-28. doi: 10.1016/j.agee.2009.07.003

[38] Patade, V.Y., Maya, K., ZaKwan, A. (2011): Seed priming mediated germination improvement and tolerance to subsequent exposure to cold and salt stress in Capsicum. Research Journal of Seed Science 4: 125-136. doi: 10.3923/rjss.2011.125.136

[39] Queiroz, C.S.D., Pereira, I.M.C., Lima, K.R.P., Bret, R.S.C., Alves, M.S., GomesFilho, E., CARVAlHO, H.H.D. (2020): Combined NaCl and DTT diminish harmful ERstress effects in the sorghum seedlings CSF 20 variety. Plant Physiology and Biochemistry 147: 223-234. doi: 10.1016/j.plaphy.2019.12.013

[40] Ratikanta, M., Dasari, R., Mangalarapu, J., Pramanik K., Yasagar, P.V. (2013): Effect of seed priming on seedling vigour and yield of tomato and chilli. International Journal of Bio-resource and Stress Management 4 (2):119-125.

[41] Rehman, H., Nawaz, Q., Basra, S.M.A., AfZal, I., Yasmeen, A. (2014): Seed priming influence on early crop growth, phenological development and yield performance of linola (Linum usitatissimum L.). Journal of Integrative Agriculture 13: 990-996.

[42] Shehzad, M., Ayub, M., Ahmad, A.U.H., Yaseen, M. (2012): Influence of priming techniques on emergence and seedling growth of forage sorghum (Sorghum bicolor L.). The Journal of Animal \& Plant Sciences 22: 154-158.

[43] Stevanović, B., Janković, M. (2001): Ekologija biljaka, Beograd.

[44] Tenorio-Berrío, R., PÉrez-Alonso, M.M., Vicente-CARbajosa, J., MArtín-Torres, L., Dreyer, I., PollmanN, S. (2018): Identification of two auxin-regulated potassium transporters involved in seed maturation. International Journal of Molecular Sciences 19 (7): 2132. doi: 10.3390/ijms19072132

[45] Tounekti, T., Mahdhi, M., Al-Faifi, Z., Khemira, H. (2020): Priming improves germination and seed reserve utilization, growth, antioxidant responses and membrane stability at early seedling stage of Saudi sorghum varieties under drought stress. Notulae Botanicae Horti Agrobotanici Cluj-Napoca 48 (2): 938-953. doi: $10.15835 / \mathrm{nbha} 48211841$

[46] Vandamme, E., Pypers, P., Smolders, E., Merckx, R. (2016): Seed weight affects shoot and root growth among and within soybean genotypes beyond the seedling stage: 
implications for low P tolerance screening. Plant Soil 401: 65-78. doi: 10.1007/s11104015-2564-8

[47] Vishnu Priya, S., Elavarasan, R., Selvan Kumar, T. (2020): Studies on radish salinity tolerance and their growth response analysis. International Journal of Advanced Research in Biological Sciences 7 (5): 30-39. doi: 10.22192/ijarbs.2020.07.05.004

[48] Wang, Y., Pan, Y., Liu, Z., Zhu, X., Zhai, L., Xu, L., LiU, L. (2013): De novo transcriptome sequencing of radish (Raphanus sativus L.) and analysis of major genes involved in glucosinolate metabolism. BMC genomics 14 (1): 1-13. doi: 10.1186/14712164-14-836.

[49] Wojtyla, Ł., Lechowska, K., Kubala, S., Garnczarska, M. (2016): Molecular processes induced in primed seeds - Increasing the potential to stabilize crop yields under drought conditions. Journal of Plant Physiology 203: 116-126. doi: 10.1016/j. jplph.2016.04.008.

[50] Zhang, M., Wang, Z., Yuan, L., Yin, C., Cheng, J., Wang, L., Huang, J., Zhang, H. (2012): Osmopriming improves tomato seed vigour under aging and salinity stress. African Journal of Biotechnology 11 (23): 6305-6311. doi: 10.5897/AJB11.3740 